\title{
Pengaruh Leverage, Ukuran Perusahaan, Profitabilitas, Kualitas Audit, dan Komite Audit terhadap Manajemen Laba
}

\author{
NIMAS ARUM SARI \\ YEYE SUSILOWATI \\ Jurusan Akuntansi, Fakultas Ekonomika dan Bisnis, Universitas Stikubank Semarang \\ Jl. Kendeng V, Bendan Ngisor, Kec. Semarang Sel., Kota Semarang, Jawa Tengah 50241 \\ Email : yeye_s@edu.unisbank.ac.id
}

Diterima 4 Desember 2020; disetujui 28 Desember 2020;

\begin{abstract}
This test is conducted in order to analyze and test the leverage, company size, profitability, and audit quality, and the audit committee in influencing earnings management. This research is sourced from an annual report from a manufacturing company on the Indonesia Stock Exchange. Starting from 2015 to 2018. Samples taken by researchers there are certain criteria in order to obtain more representative data. So that a total sample of 327 manufacturing companies was obtained during the study period. Researchers used secondary data, the data obtained through the site www.idx.co.id, www.sahamok.com, and several related company websites. This data analysis tool uses multiple linear regression. The end of this test includes evidence in the form of leverage and audit committee which has a positive and significant effect on earnings management, while company size, profitability and audit quality have no effect on earnings management.
\end{abstract}

Keywords: Leverage, Company Size, Profitability, Audit quality, Audit committee, and Earnings Management.

\section{PENDAHULUAN}

Teori agensi menyatakan adanya hubungan kerja antara pihak yang memberi wewenang (principal) dengan pihak yang menerima wewenang (agent) dalam bentuk sebuah kontrak kerjasama tercipta karena adanya kepentingan yang saling bertentangan (Pangestuti dan Susilowati, 2017). Teori ini mengasumsikan bahwa antara investor dan manajer sama-sama memiliki kepentingan masing-masing. Tapi dalam kenyataannya, pihak manajemen lebih memiliki akses untuk mencapai kepentingan pribadinya. Dan untuk mewujudkan hal itu maka manajer melakukan tindakan manajemen laba.
Manajemen laba merupakan aktivitas manajerial untuk mempengaruhi laporan keuangan baik dengan cara memanipulasi data atau informasi keuangan perusahaan maupun dengan pemilihan metode akuntansi yang diterima dalam prinsip akuntansi (Aditama, 2013) dalam (Wardani dan Santi, 2018). Manajemen laba dapat dipengaruhi oleh beberapa variabel, diantaranya Leverage, Ukuran Perusahaan, Profitabilitas, Kualitas Audit, dan Komite Audit

Leverage merupakan rasio untuk menguji sejauh mana perusahaan menggunakan utang yang dipinjam (Susilowati dkk, 2018). Peningkatan tingkat bunga, negosiasi ulang masa hutang serta percepatan jatuh tempo 
adalah dampak dari pelanggaran perjanjian kontrak hutang. Hutang dapat meningkatkan manajemen laba saat perusahaan ingin mengurangi kemungkinan pelanggaran perjanjian kontrak hutang dan meningkatkan posisi tawar perusahaan selama masa negosiasi hutang. Berdasarkan penelitian yang dilakukan oleh Astari dan Suryanawa (2017), Indracahya dan Faisol(2017), Giovani(2017) memberikan hasil bahwa leverage berpengaruh positif terhadap manajemen laba. Akan tetapi Gunawan dkk (2015) menyatakan bahwa leverage tidak berpengaruh terhadap manajemen laba, dan Pasilongi dkk (2018) menyatakan bahwa leverage berpengaruh dengan arah negatif.

Ukuran perusahaan merupakan nilai yang menunjukkan besar kecilnya suatu perusahaan. Investor dalam menanamkan modalnya akan memilih perusahaan yang memiliki reputasi yang baik dan perusahaan yang mampu menunjukkan kinerja yang baik agar modal yang ditanamkan dapat menguntungkan bagi dirinya. Perusahaan besar akan lebih diperhatikan oleh pihak luar sehingga membuat pihak manjemen lebih teliti dalam mengelola keuangan perusahaan. Dan manajer cenderung enggan melakukan tindakan manajemen laba agar tetap terjaga reputasi perusahaannya. Oleh peneliti Giovani (2017) serta Wardani dan Santi (2018) menyatakan bahwa ukuran perusahaan berpengaruh negatif dan signifikan terhadap manajemen laba. Sedangkan peneliti Gunawan dkk (2015), Arifin dan Destriana (2016) serta Indracahya dan Faisol (2017) menyatakan bahwa ukuran perusahaan tidak berpengaruh terhadap manajemen laba.

Profitabilitas menggambarkan kemampuan perusahaan dalam menghasilkan laba selama satu periode waktu tertentu. Pada umumnya nilai profitabilitas digunakan sebagai indikator untuk mengukur kinerja manajemen suatu perusahaan. Ketertakaitan antara profitabilitas dengan manajemen laba adalah ketika profitabilitas yang diperoleh perusahaan kecil pada periode waktu tertentu akan memicu perusahaan untuk melakukan manajemen laba, ataupun ketika suatu perusahaan yang mengalami kerugian yang cukup besar dan mengalami kelonjakan profit yang cukup fantastis pada periode waktu berikutnya hal itu diindakasi adanya manajemen laba. Berdasarkan hasil penelitian yang dilakukan Herni dan Susanto (2008), Purwandari (2011) menyatakan bahwa profitabilitas berpengaruh negatif terhadap manajemen laba, serta Anggraini (2005) juga berpendapat bahwa profitabilitas berpengaruh negatif terhadap manajemen laba sedangkan menurut Astari dan Suryanawa (2017), Indracahya dan Faisol (2017), Giovani (2017) serta Devi dan Iskak (2018) menyatakan bahwa profitabilitas berpengaruh positif dan signifikan terhadap manajemen laba, Gunawan dkk (2015), Amelia dan Hernawati (2016) serta Agustia dan Suryani (2018) memberikan bukti bahwa profitabilitas tidak berpengaruh terhadap manajemen laba.

Pemeriksaaan yang dilakukan oleh auditor memiliki kualitas yang berbedabeda. Oleh karena itu auditing yang berkualitas tinggi bertindak sebagai pencegah manajemen laba yang aktif, karena reputasi manajemen dan nilai perusahaan akan turun apabila pelaporan yang salah ini terdeteksi dan terungkap. Berdasarkan hasil penelitian dari Amijaya dan Prastiwi (2013) memberikan hasil penelitian berupa kualitas audit berpengaruh negatif dan signifikan terhadap manajemen laba dan Pasilongi dkk (2018) bahwa kualitas audit berpengaruh signifikan dengan arah negatif terhadap manajemen laba. Sedangkan hasil penelitian dari Devi dan Iskak (2018) serta Hadi dan Tifani (2020) menyatakan bahwa kualitas audit 
memiliki pengaruh positif terhadap manajemen laba. Farida (2020) memberikan pernyataan bahwa kualitas audit tidak berpengaruh terhadap manajemen laba.

Keberadaan komite audit di dalam perusahaan diharapkan mampu berkontribusi dalam menjaga perusahaan agar menjadi lebih baik melalui peninjauan informasi keuangan, juga dapat meningkatkan kualitas pengawasan internal perusahaan dan memaksimalkan proses pengecekan laporan keuangan, sehingga dapat melindungi para pemilik dan stakeholder lainnya (Perdana, 2019). Sehingga adanya komite audit dalam perusahaan, kesempatan untuk melakukan tindakan kecurangan laporan keuangan ataupun manajemen laba bisa dihindarkan. Apabila banyak jumlah rapat komite audit yang diadakan, maka akan mampu mengurangi atau membatasi tindakan manajemen laba (Yendrawati dan Yuanifa, 2015). Berdasarkan penelitian yang dilakukan oleh Marsha dan Ghozali (2017) menunjukkan hasil bahwa jumlah rapat komite audit berpengaruh negatif terhadap manajemen laba, sedangkan penelitian yang dilakukan oleh Pamudji dan Trihartati (2010) dan Perdana (2019) serta menunjukkan hasil jumlah rapat komite audit berpengaruh positif terhadap manajemen laba. Suaidah dan Utomo (2018) menyatakan bahwa komite audit tidak berpengaruh terhadap manajemen laba.

\section{TINJAUAN TEORETIS}

Teori Agensi. Teori agensi merupakan sebuah kontrak antara pihak manajemen (agent) dengan pemilik atau pemegang saham (principal). Pemegang saham (principal) memperkerjakan manajer (agent) yang bertindak atas nama pemegang saham (principal) untuk mengelola perusahaan (Jensen dan Meckling, 1976). Teori agensi mendasarkan hubungan kontrak antara pemilik (principal) dan manajer (agent) sulit tercipta karena adanya kepentingan yang saling bertentangan (conflict of interest).

Pengaruh Leverage terhadap Manajemen Laba. Leverage merupakan rasio antara total kewajiban dengan total modal. Semakin besar rasio leverage, berarti semakin tinggi nilai utang perusahaan. Perusahaan yang mempunyai rasio leverage tinggi, berarti perusahaan melakukan pinjaman jangka panjang yang besar yang dapat meningkatkan resiko kebangkrutan, sehingga perusahaan akan cenderung melakukan manipulasi dalam bentuk manajemen laba dengan tujuan untuk menghindari pelanggaran perjanjian utang. Astari dan Suryanawa (2017) meneliti pengaruh leverage terhadap manajemen laba pada perusahaan manufaktur yang terdaftar di Bursa Efek Indonesia (BEI) menunjukkan bahwa leverage berpengaruh positif dan signifikan pada manajemen laba. Berdasarkan uraian tersebut, maka dapat dibuat hipotesis sebagai berikut:

H1 : Leverage berpengaruh positif dan signifikan terhadap manajemen laba.

Pengaruh Ukuran Perusahaan terhadap Manajemen Laba. Ukuran perusahaan didefinisikan sebagai upaya penilaian besar atau kecilnya sebuah perusahaan. Perusahaan dengan ukuran yang besar akan dilihat kiner-janya oleh publik sehingga perusahaan akan melaporkan kondisi keuangannya dengan hati-hati dan transparan, sehingga kemungkinan besar lebih sedikit perusahaan besar melakukan manajemen laba untuk mempercantik laba yang dihasilkan. Sedangkan perusahaan kecil mempunyai tingkat kecenderungan untuk melakukan manajemen laba dengan cara melaporkan laba yang tinggi untuk menunjukkan kinerja perusahaan yang memuaskan. Wardani dan Santi (2018) melakukan penelitian tentang penga- 
ruh ukuran perusahaan terhadap manajemen laba pada perusahaan manufaktur sub sektor makanan dan minuman tahun 2012-2016 dengan hasil bahwa ukuran perusahaan berpengaruh negatif dan signifikan terhadap manajemen laba. Berdasarkan uraian tersebut, maka dapat dibuat hipotesis sebagai berikut :

H2 : Ukuran perusahaan berpengaruh negatif dan signifikan terhadap manajemen laba.

Pengaruh Profitabilitas terhadap Manajemen Laba. Profitabilitas menunjukkan kemampuan manajemen dalam menghasilkan laba dengan memanfaatkan aset yang digunakan dalam kegiatan operasionalnya. Semakin tinggi rasio profitabilitas semakin baik tingkat efektivitas manajemen suatu perusahaan. Keterkaitan antara profitablitas dengan manajemen laba adalah ketika profitabilitas yang diperoleh perusahaan kecil pada waktu tertentu akan memicu perusahaan melakukan manajemen laba dengan cara meningkatkan pendapatan yang diper-oleh sehingga akan memperlihatkan saham dan mempertahankan investor yang ada. Menurut Herni dan Susanto (2008), dan Purwandari (2011) serta Anggraini (2005) mengemukakan bahwa profitabilitas berpengaruh negatif terhadap manajemen laba. Berdasarkan uraian tersebut, maka dapat dibuat hipotesis sebagai berikut :

H3 : Profitabilitas berpengaruh negatif dan signifikan terhadap manajemen laba.

Pengaruh Kualitas Audit terhadap Manajemen Laba. Auditor yang berkualitas adalah auditor yang bisa memberikan informasi yang akurat. Informasi yang akurat adalah informasi yang bisa dengan tepat menunjukkan nilai perusahaan. De Angelo (1981) mendefinisikan kualitas audit sebagai probabilitas dimana seorang auditor menemukan dan melaporkan tentang adanya suatu pelanggaran dalam sistem akuntansi kliennya. Hasil penelitiannya menunjukkan bahwa KAP yang besar akan berusaha untuk menyajikan kualitas audit yang lebih besar dibandingkan dengan KAP yang kecil. KAP yang besar jika tidak memberikan kualitas audit yang tinggi akan kehilangan reputasinya, dan jika ini terjadi maka dia akan mengalami kerugian yang lebih besar dengan kehilangan kepercayaan klien. Pasilongi dkk (2018) menyatakan bahwa kualitas audit berpengaruh negatif terhadap manajemen laba. Berdasarkan uraian tersebut, maka dapat dibuat hipotesis sebagai berikut :

H4 : Kualitas audit berpengaruh negatif dan signifikan terhadap manajemen laba.

\section{Pengaruh Komite Audit terhadap} Manajemen Laba. Ikatan Komite Audit Indonesia (IKAI) menegaskan keberadaan komite audit diharapkan mampu meningkatkan kualitas pengawasan internal perusahaan, serta mampu mengoptimalkan mekanisme checks and balances, yang pada akhirnya ditujukan untuk memberikan perlindungan optimum kepada para pemegang saham dan stakeholder lainnya (Perdana, 2019). Sehingga dengan adanya komite audit pada suatu perusahaan, peluang untuk melakukan tindakan manipulasi laporan keuangan maupun manajemen laba dapat dihindarkan. Semakin banyak jumlah rapat komite audit yang diadakan, maka akan mampu mengurangi tindakan manajemen laba (Yendrawati dan Yuanifa, 2015). Berdasarkan penelitian yang dilakukan oleh Marsha dan Ghozali (2017) menunjukkan hasil bahwa jumlah rapat komite audit berpengaruh negatif terhadap manajemen laba. Berdasarkan uraian tersebut, maka dapat dibuat hipotesis sebagai berikut:

H5 : Komite audit berpengaruh negatif dan signifikan terhadap manajemen laba. 
Tabel 1

Hasil Uji Regresi

\begin{tabular}{|c|c|c|c|c|c|}
\hline \multirow[b]{2}{*}{ Model } & \multicolumn{2}{|c|}{$\begin{array}{c}\text { Unstandardized } \\
\text { Coefficients }\end{array}$} & \multirow{2}{*}{$\begin{array}{c}\begin{array}{c}\text { Standardized } \\
\text { Coefficients }\end{array} \\
\text { Beta }\end{array}$} & \multirow[b]{2}{*}{$\mathrm{t}$} & \multirow[b]{2}{*}{ Sig. } \\
\hline & $\bar{B}$ & Std. Error & & & \\
\hline 1 (Constant) &,- 041 & ,363 & &,- 113 & 910 \\
\hline DER & 059 & ,018 & , 191 & 3,233 & ,001 \\
\hline LAGSIZE &,- 001 & ,012 &,- 005 &,- 078 & ,938 \\
\hline ROA & 141 & 173 &, 050 & ,816 & ,415 \\
\hline KUA &,- 013 &, 041 &,- 020 &,- 327 &, 744 \\
\hline $\mathrm{KA}$ & ,128 & ,061 & , 126 & 2,107 & 036 \\
\hline
\end{tabular}

a. Dependent Variable: DA

\section{METODE PENELITIAN}

Populasi dan Sampel. Populasi dalam penelitian ini adalah perusahaan manufaktur yang terdaftar di Bursa Efek Indonesia selama 4 tahun yaitu pada periode 2015-2018. Pengambilan sampel dilakukan dengan metode purposive sampling.

Analisis Linier Berganda. Analisis regresi berganda digunakan untuk mengetahui pengaruh antara variabel bebas dalam mempengaruhi variabel tidak bebas secara bersamasama ataupun secara parsial.

\section{HASIL DAN PEMBAHASAN}

Analisis Deskriptif. Populasi dan sampel dalam penelitian ini sebanyak 327 data perusahaan manufaktur yang terdaftar di Bursa Efek Indonesia. Dari sampel yang berjumlah 327 terdapat beberapa data outlier, sehingga harus dilakukan reduksi data. Setelah dilakukan reduksi data, maka jumlah sampel keseluruhan adalah 295.

Uji Regresi Linier Berganda. Hasil dari pengujian regresi dapat dilihat pada tabel 1. Persamaan model regresi adalah sebagai berikut :

$$
\begin{aligned}
\mathrm{DA}= & -0,041+0,059 \mathrm{DER}-0,001 \mathrm{LAGSIZE} \\
& +0,141 \mathrm{ROA}-0,013 \mathrm{KUA} 0,128 \mathrm{KA}+\varepsilon
\end{aligned}
$$

Pengaruh Leverage terhadap Manajemen Laba. Berdasarkan hasil uji t yang telah dilakukan di atas menunjukkan bahwa variabel leverage (DER) terhadap manajemen laba diperoleh nilai signifikan sebesar 0,001 sehingga lebih kecil dari tingkat signifikan yaitu 0,05. Dapat dikatakan bahwa hipotesis pertama (H1) yang berbunyi "leverage berpe ngaruh positif dan signifikan terhadap manajemen laba" diterima. Ketika perusahaan memiliki jumlah utang yang besar maka perusahaan cenderung mempunyai risiko bisnis tinggi, karena perusahaan dikhawatirkan tidak dapat membayar jumlah hutang yang ada. Sehingga mengakibatkan terjadinya pelanggaran kontrak hutang.

Hal tersebut menjadi pemicu pihak manajemen untuk melakukan tindakan manajemen laba untuk menghindari risiko pelanggaran perjanjian kontrak hutang. Teori keagenan, berasumsi bahwa setiap individu termotivasi oleh kepentingan kesejahteraan dan kepentingan pribadi. Entah itu pihak manajemen (agent) maupun pihak pemegang saham (principal) samasama memiliki tujuan untuk kepentingan pribadi masing-masing. Oleh karena itu, pihak manajemen berusaha melakukan upaya untuk memperlihatkan bahwa kinerja 
dari perusahaan terlihat baik melalui laporan keuangan yang menunjukkan perolehan laba tinggi. Pernyataan ini didukung oleh penelitian Astari dan Suryanawa (2017) leverage berpengaruh positif dan signifikan terhadap manajemen laba artinya jika perusahaan memiliki leverage yang tinggi maka tindakan manajemen laba yang dilakukan akan meningkat.

Pengaruh Ukuran Perusahaan terhadap Manajemen Laba. Berdasarkan hasil uji $\mathrm{t}$ yang telah dilakukan menunjukkan bahwa variabel ukuran perusahaan (LAG SIZE) terhadap manajemen laba diperoleh hasil signifikansi sebesar 0,938 sehingga lebih besar dari tingkat signifikan yaitu 0,05. Dapat dikatakan bahwa hipotesis pertama (H2) yang berbunyi : "ukuran perusahaan berpengaruh negatif dan signifikan terhadap manajemen laba" ditolak.

Dari hasil penelitian dapat diketahui variabel ukuran perusahaan tidak berpengaruh terhadap manajemen laba. Hal tersebut menunjukkan bahwa ukuran perusahaan tidak ada kaitannya dengan tindakan manajemen laba. Karena manajemen laba dilakukan oleh orang atau manajemen perusahaan, bukan berdasarkan pengaruh dari seberapa besar ukuran perusahaan. Ini membuktikan bahwa dengan ukuran perusahaan yang besar belum tentu menjamin dapat mempengaruhi atau menurunkan tindakan manajemen laba, begitu pula sebaliknya ukuran perusahaan yang kecil belum tentu juga melakukan tindakan manajemen laba.

Ukuran perusahaan yang besar maupun kecil tidak akan mempengaruhi hubungan kontraktual antara pemilik atau pemegang saham dengan pihak manajer atau pengelola karena tidak akan menimbulkan konflik diantara kedua belah pihak. Ukuran perusahaan bukan menjadi faktor pemicu tindakan manajer dalam melakukan tindakan manajemen laba, sehingga laporan keuangan yang disajikan oleh pihak manajer cenderung menggambarkan keadaan yang sesungguhnya tentang hasil kinerja selama ini. Hasil penelitian ini didukung oleh penelitian dari Gunawan dkk (2015), Arifin dan Destriani (2016), Indracahya dan Faisol (2017), dan Pasiolongi dkk (2018) yang menyatakan bahwa ukuran perusahaan tidak berpengaruh terhadap manajemen laba.

\section{Pengaruh Profitabilitas terhadap Ma-} najemen Laba. Berdasarkan hasil uji t yang telah dilakukan menunjukkan bahwa variabel profitabilitas (ROA) terhadap manajemen laba diperoleh hasil signifikan sebesar 0,415 sehingga lebih besar dari tingkat signifikan yaitu 0,05. Dapat dikatakan bahwa hipotesis ketiga (H3) yang berbunyi : "profitabilitas berpengaruh negatif dan signifikan terhadap manajemen laba" ditolak.

Hasil pengujian pengaruh profitabilitas terhadap manajemen laba dalam penelitian ini menyimpulkan bahwa profitabilitas tidak berpengaruh terhadap manajemen laba. Hal tersebut juga dikarenakan investor cenderung mengabaikan informasi ROA yang ada sehingga manajemen pun menjadi tidak termotivasi melakukan manajemen laba melalui variabel profitabilitas, (Bestiano, 2013) dalam (Agustia dan Suryani, 2018).

Hasil penelitian ini serupa dengan penelitian yang dilakukan oleh Gunawan dkk (2015), Amelia dan Hernawati (2016), Wardani dan Isbela (2017), dan Agustia dan Suryani (2018). Yang menyatakan bahwa profitabilitas tidak berpengaruh terhadap manajemen laba.

Pengaruh Kualitas Audit terhadap Manajemen Laba. Berdasarkan hasil uji t yang terlah dilakukan menunjukkan bahwa variabel kualitas audit (KUA) diperoleh nilai signifikan 0,744 sehingga lebih besar dari tingkat signifikan yaitu 0,05 dapat dikatakan bahwa hipotesis keempat (H4) yang berbunyi: "kualitas audit berpengaruh nega- 
tif dan signifikan terhadap manajemen laba" ditolak.

Dari hasil penelitian dapat diketahui variabel kualitas audit tidak berpengaruh terhadap manajemen laba. Tindakan manajemen laba terjadi karena adanya keinginan atau motivasi pihak manajemen untuk memperlihatkan kinerja keuangan yang baik didepan para investor, sehingga ukuran KAP dalam hal ini diabaikan oleh pihak manajemen (Agency Theory). Di sisi lain, investor tidak sepenuhnya mengambil keputusan berdasarkan informasi laporan auditor independen yang dilaporkan KAP. Hal tersebut sesuai dengan penelitian yang dilakukan oleh Asyati dan Farida (2020) yang menyatakan bahwa kualitas audit tidak berpengaruh terhadap manajemen laba.

Pengaruh Komite Audit terhadap Manajemen Laba. Berdasarkan hasil uji $t$ yang telah dilakukan menunjukkan bahwa variabel komite audit terhadap manajemen laba diperoleh hasil signifikan 0,036 sehingga lebih kecil dari tingkat signifikan yaitu 0,05 . Namun memiliki tanda positif $(+)$. Sehingga dapat dikatakan bahwa hipotesis keempat (H5) yang berbunyi: "komite audit berpengaruh negatif dan signifikan terhadap manajemen laba" ditolak.

Berdasarkan hasil penelitian ini, komite audit belum mampu berperan dalam mengatasi ataupun mencegah tindakan manajemen laba di perusahaan yang dijadikan obyek penelitian. Hal itu terjadi mungkin karena pembentukan komite audit dan rapat yang diadakan oleh perusahaan hanya untuk memenuhi regulasi atau peraturan saja bukan untuk menjalankan Good Corporate Governance. Sehingga, keberadaan komite audit kurang efektif dalam mengatasi permasalahan manajemen laba.

Hasil penelitian ini sejalan dengan penelitian yang dilakukan oleh Pamudji dan Trihartati (2010), Perdana (2019) yang memberikan hasil bahwa komite audit berpengaruh positif dan signifikan terhadap manajemen laba.

\section{SIMPULAN}

Kesimpulan. Berdasarkan hasil penelitian dan pembahasan maka simpulan yang diperoleh dari penelitian ini adalah :

1. Leverage berpengaruh positif dan signifikan terhadap manajemen laba.

2. Ukuran perusahaan tidak berpengaruh terhadap manajemen laba.

3. Profitabilitas tidak berpengaruh terhadap manajemen laba.

4. Kualitas audit tidak berpengaruh terhadap manajemen laba.

5. Komite audit berpengaruh positif dan signifikan terhadap manajemen laba.

\section{DAFTAR PUSTAKA}

Agustia, Yofi Prima., dan Suryani, Elly. (2018). Pengaruh Ukuran Perusahaan, Umur Perusahaan, Leverage, dan Profitabilitas Terhadap Manajemen Laba Studi pada Perusahaan Pertambangan yang Terdaftar di Bursa Efek Indonesia Tahun 2014-2016. Jurnal ASET (Akuntansi Riset). Vol 10, No 1: 63-74.

Amelia, Winda., dan Hernawati, Erna. (2016). Pengaruh Komisaris Independen, Ukuran Perusahaan, dan Profitabilitas Terhadap Manajemen Laba. Jurnal Neo-Bis. Vol 10, No 1 : 62-77.

Amijaya, Muhammad Dody., dan Prastiwi, Andri. (2013). Pengaruh Kualitas Audit Terhadap Manajemen Laba. Diponegoro Journal of Accounting. Vol 2, No 3 : 1-13. ISSN: 2337-3806.

Anggraini, F. 2005. Pengaruh Konsentrasi Kepemilikan Manajerial, Pangsa Pasar dan Profitabilitas Terhadap Status Pemerataan Laba (Income Smoothing). Jurnal Ekonomi STEI No. 2/Th. XIV/29/April-Juni, hal: 1529. 
Arifin, Lavenia., dan Destriana, Nicken. (2016). Pengaruh Firm Size, Corporate Governance, dan Karakteristik Perusahaan Terhadap Manajemen Laba. Jurnal Bisnis dan Akuntansi. Vol 18, No 1 : 84-93.

Asyati, Farida., dan Farida. (2020). Pengaruh Good Corporate Governance, Leverage, Profitabilitas, dan Kualitas Audit Terhadap Manajemen Laba Studi Empiris pada Perusahaan Manufaktur yang Terdaftar di BEI Periode 2014-2018. Jurnal of Economic, Management, Accounting and Technology (JEMATech). Vol 3, No 1 : 36-48. ISSN: 2622-8394.

Astari, A.A.M.R., dan Suryanawa, I K. (2017). Faktor-faktor yang Mempengaruhi Manajemen Laba. E-Jurnal Akuntansi Universitas Udayana. Vol 20, No 1: 290-319. ISSN:2302-8556.

De Angelo, L.E. 1981. Auditor Size and Audit Quality. Journal of Accounting and Economic. 183-199.

Devi, Clarissa Maya., dan Iskak, Jamaludin. (2018). Pengaruh Corporate Governance, Profitabilitas, Leverage, dan Kualitas Audit Terhadap Real Earning Management. Jurnal Muara Ilmu Ekonomi dan Bisnis. Vol 2, No 1: 35-43. ISSN: 2579-6224.

finance.detik.com/industri/d-2972287/kasusskandal-keuangan-ceo-toshiba-mundur. 2015. Diakses Pada 06 Juli 2019

Ghozali, I. (2018). Aplikasi Analisis Multivariate dengan Program IBM SPSS 25. Edisi Kesembilan. Semarang: Badan Penerbit Universitas Diponegoro

Giovani, Marsheila. (2017). Pengaruh Struktur Kepemilikan, Tata Kelola Perusahaan, dan Karakteristik Perusahaan Terhadap Manajemen Laba. Jurnal Akuntansi Bisnis. Vol 15, No 2: 290-306. ISSN: 1412-775X.

Agustia, Yofi Prima., dan Suryani, Elly. (2018). Pengaruh Ukuran Perusahaan, Umur Perusahaan, Leverage, dan Profitabilitas Terhadap Manajemen Laba Studi pada Perusahaan Pertambangan yang Terdaftar di Bursa Efek Indonesia Tahun 2014-2016. Jurnal ASET (Akuntansi Riset). Vol 10, No 1: 63-74.
Amelia, Winda., dan Hernawati, Erna. (2016). Pengaruh Komisaris Independen, Ukuran Perusahaan, dan Profitabilitas Terhadap Manajemen Laba. Jurnal Neo-Bis. Vol 10, No $1: 62-77$.

Amijaya, Muhammad Dody., dan Prastiwi, Andri. (2013). Pengaruh Kualitas Audit Terhadap Manajemen Laba. Diponegoro Journal of Accounting. Vol 2, No 3 : 1-13. ISSN: 2337-3806.

Anggraini, F. 2005. Pengaruh Konsentrasi Kepemilikan Manajerial, Pangsa Pasar dan Profitabilitas Terhadap Status Pemerataan Laba (Income Smoothing). Jurnal Ekonomi STEI No. 2/Th. XIV/29/April-Juni, hal: 1529.

Arifin, Lavenia., dan Destriana, Nicken. (2016). Pengaruh Firm Size, Corporate Governance, dan Karakteristik Perusahaan Terhadap Manajemen Laba. Jurnal Bisnis dan Akuntansi. Vol 18, No 1 : 84-93.

Asyati, Farida., dan Farida. (2020). Pengaruh Good Corporate Governance, Leverage, Profitabilitas, dan Kualitas Audit Terhadap Manajemen Laba Studi Empiris pada Perusahaan Manufaktur yang Terdaftar di BEI Periode 2014-2018. Jurnal of Economic, Management, Accounting and Technology (JEMATech). Vol 3, No 1 : 3648. ISSN: 2622-8394.

Astari, A.A.M.R., dan Suryanawa, I K. (2017). Faktor-faktor yang Mempengaruhi Manajemen Laba. E-Jurnal Akuntansi Universitas Udayana. Vol 20, No 1: 290-319. ISSN:2302-8556.

De Angelo, L.E. 1981. Auditor Size and Audit Quality. Journal of Accounting and Economic. 183-199.

Devi, Clarissa Maya., dan Iskak, Jamaludin. (2018). Pengaruh Corporate Governance, Profitabilitas, Leverage, dan Kualitas Audit Terhadap Real Earning Management. Jurnal Muara Ilmu Ekonomi dan Bisnis. Vol 2, No 1: 35-43. ISSN: 2579-6224.

finance.detik.com/industri/d-2972287/kasusskandal-keuangan-ceo-toshiba-mundur. 2015. Diakses Pada 06 Juli 2019 
Ghozali, I. (2018). Aplikasi Analisis Multivariate dengan Program IBM SPSS 25. Edisi Kesembilan. Semarang: Badan Penerbit Universitas Diponegoro

Giovani, Marsheila. (2017). Pengaruh Struktur Kepemilikan, Tata Kelola Perusahaan, dan Karakteristik Perusahaan Terhadap Manajemen Laba. Jurnal Akuntansi Bisnis. Vol 15, No 2: 290-306. ISSN: 1412-775X.

Gunawan, dkk. (2015). Pengaruh Ukuran Perusahaan, Profitabilitas, dan Leverage Terhadap Manajemen Laba pada Perusahaan Manufaktur yang Terdaftar di Bursa Efek Indonesia (BEI). E-Journal S1 Ak Universitas Pendidikan Ganesha. Vol 3, No 1.

Hadi, Felita Icasia., dan Tifani, Sherly. (2020). Pengaruh Kualitas Audit dan Auditor Switching Terhadap Manajemen Laba. Jurnal Bisnis dan Akuntansi. Vol 22, No 1: 95-104. ISSN: 1410-9875.

Herni, dan Susanto, Yulius kurnia. (2008). Pengaruh Struktur Kepemilikan Publik, Praktik Pengelolaan Perusahaan, Jenis Industri, Ukuran Perusahaan, Profitabilitas dan Risiko Keuangan Terhadap Tindakan Perataan Laba (Studi Empiris pada Industri yang Listing di Bursa Efek Jakarta. Jurnal Ekonomi dan Bisnis Indonesia. Vol 23, No 3.

Indracahya, Erik, dan Faisol, Dewi A. (2017). The Effect of Good Corporate Governance Element, Leverage, Firm Age, Company Size and Profitability on Earning Management Empirical Study of Manufacturing Companies in BEI 2014-2016. Jurnal PROFITA. Vol 10, No 2: 203-227.

Investasi.kontan.co.id/news/investor-aisa-kasusaisa-adalah-skandal-dalam-pasar-modalindonesia. 2017. Diakses pada tanggal 17 Juni 2020.

Jensen, M.C., dan Meckling, W.H. (1976). Theory Of The Firn: Managerial Behavior, Agency Cost And Ownership Structure. Journal of financial economics. 305-360.

Kasiram, Mohammad. (2008). Metode Penelitian Kuantitatif-Kualitatif. Malang: UIN Malang Press.
Marsha, Felicia, dan Ghozali, Imam. (2017). Pengaruh Ukuran Komite Audit, Audit Eksternal, Jumlah Rapat Komite Audit, Jumlah Rapat Dewan Komisaris dan Kepemilikan Institusional Terhadap Manajemen Laba Studi Empiris pada Perusahaan Manufaktur yang Terdaftar di BEI Tahun 2012-2014. E-Journal S1Undip. Vol 6, No 2: 1-12. ISSN: 2337-3814.

Money.kompas.com/2015/07/21/161317026/.Bo s.Toshiba.Dilaporkan.Terlibat.Skandal.Pen yimpangan. Akuntansi.?page=1. 2015 . Diakses pada Tanggal 06 Juli 2019.

Pangestuti, Kartiko Dewi., dan Susilowati, Yeye. (2017). Komisaris Endependen, Reputasi Auditor, Konsentrasi Kepemilikan, dan Ukuran Perusahaan Terhadap Pengungkapan Enterprise Risk Management. Dinamika Akuntansi, Keuangan dan Perbankan. Vol 06, No 02: 164-175. ISSN: 2656-4955.

Pamudji, Sugeng, dan Trihartati, Aprillya. (2010). Pengaruh Independensi dan Efektivitas Komite Audit Terhadap Manajemen Laba. Jurnal Dinamika Akuntansi. Vol 2, No 1.

Pasiolongi, dkk. (2018). Pengaruh Kualitas Audit, Profitabilitas, dan Ukuran Perusahaan Terhadap Manajemen Laba Studi Kasus pada Sektor Industri Barang Konsumsi yang Terdaftar di Bursa Efek Indonesia Tahun 2013-2016. E-Proceeding of Management. Vol 5, No 2: 1-11. ISSN: 2355-9357.

Perdana, A.A. (2019). Pengaruh Kepemilikan Institusional, Leverage dan Komite Audit Terhadap Manajemen Laba pada Perusahaan yang Terdaftar di Bursa Efek Indonesia Tahun 2015-2017. Jurnal Ekonomi Sakti. Vol 8, No 1: 1-19. ISSN: 2685-1849.

Selviani, A.H. (2017). Pengaruh Profitabilitas, Leverage, dan Ukuran Perusahaan Terhadap Manajemen Laba Studi Empiris pada Perusahaan Manufaktur yang Terdaftar di Bursa Efek Indonesia Tahun 2014-2016. Skripsi. Yogyakarta: Ekonomi Universitas Sanata Dharma. 
Suaidah, Y. M., dan Utomo, L.P. (2018). Pengaruh Mekanisme Good Corporate Governance dan Profitabilitas Terhadap Manajemen Laba. Jurnal Ekonomi dan Bisnis. Vol 20, No 2:120-130. ISSN: 16938852.

Subramanyam, \& John, J. W. 2012. Analisis Laporan Keuangan. Jakarta: Salemba Empat.

Sugiyono. (2010). Metode Penelitian Kuantitatif, Kualitatif dan R\&D. Bandung: CV. Alfabeta

Suharyadi dan Purwanto, S.K. (2011). Statistika untuk Ekonomi dan Keuangan Modern. Jakarta: Salemba Empat.

Surat Keputusan BAPEPAM-LK No. KEP643/BL/2012. Tentang Pembentukan dan Pedoman Pelaksanaan Kerja Komite Audit. 2012.

Susilowati, $d k k$. (2018). Pengaruh Ukuran Perusahaan, Leverage, Profitabilitas, Capital Intensity Ratio, dan Komisaris Independen Terhadap Effective Tax Rate (Studi Empiris pada Perusahaan Manufaktur yang Terdaftar di Bursa Efek
Indonesia pada Tahun 2014-2016). Prosiding SENDI_U 2018. ISBN: 978-9793649-99-3.

Wardani, D.K., dan Isbela, P.D. (2017). Pengaruh Strategi Bisnis dan Karakteristik Perusahaan Terhadap Manajemen Laba. JRAK. Vol 13, No 2.

Wardani, D.K., dan Santi, D.K. (2018). Pengaruh Tax Planning, Ukuran Perusahaan, Corporate Social Responsilbility (CSR) Terhadap Manajemen Laba. Jurnal Akuntansi Vol. 6 No. 1: 11-24.

www.googlescholar.com www.idx.co.id www.sahamok.com

Yendrawati, Ren, dan Yuanifa, Entria. (2015). Pengaruh Dewan Komisaris Independen, Komite Audit, Kepemilikan Manajerial dan Kepemilikan Institusional Terhadap Manajemen Laba. Jurnal Entrepreneur dan Entrepreneurship. Vol 4, No 